\title{
Decolorization of an azo dye, Reactive Black 5 and MnP production by yeast isolate: Debaryomyces polymorphus
}

\author{
Qingxiang Yang ${ }^{\mathrm{a}, \mathrm{c}}$, Ayfer Yediler $^{\mathrm{b}, *}$, Min Yang $^{\mathrm{c}}$, Antonius Kettrup $^{\mathrm{b}}$ \\ a College of Life Sciences, Henan Normal University, Key Laboratory of Environmental Pollution Control Technology of Henan Province, \\ Xinxiang, Henan 453002, China \\ b Institute of Ecological Chemistry, GSF-National Research Center for Environment and Health, Ingolstaedter Landstraße 1, \\ D-85764 Neuherberg, Germany \\ c State Key Laboratory of Environmental Aquatic Chemistry, Research Center for Eco-Environmental Sciences, \\ CAS, P.O. Box 2871, Beijing 100085, China
}

Received 15 September 2004; accepted 25 December 2004

\begin{abstract}
The optimum conditions for decolorization of an azo dye, C.I. Reactive Black 5 (RB5) and the kinetic characteristics of manganesedependent peroxidase (MnP) production by yeast isolate, Debaryomyces polymorphus, were investigated. D. polymorphus could completely degrade $200 \mathrm{mg} \mathrm{l}^{-1}$ of non-hydrolyzed and hydrolyzed C.I. Reactive Black 5 within $24 \mathrm{~h}$ of cultivation at an inoculum size of $1.4 \mathrm{~g} \mathrm{l}^{-1}$ wet cells in $50 \mathrm{ml}$ medium consisting of $5 \mathrm{~g} \mathrm{l}^{-1}$ glucose and $0.5-1.0 \mathrm{~g} \mathrm{l}^{-1}$ ammonium sulphate ( $\mathrm{pH} 5-7$ ). In addition, the MnP activities during the cultivation were evaluated in the absence and presence of $200 \mathrm{mg}^{-1}$ C.I. Reactive Black 5. Maximum activity of MnP (1555.6 U1 $\left.1^{-1}\right)$ was detected at $24 \mathrm{~h}$ cultivation in the presence of the dye, and a significant reduction of the enzyme activity was observed thereafter. The presence of C.I. Reactive Black 5 in the culture was found to be indispensable to the production of MnP by D. polymorphus. A good correlation was found between the dye degradation and the enzyme production.
\end{abstract}

(C) 2005 Elsevier B.V. All rights reserved.

Keywords: Decolorization; Yeast; Manganese-dependent peroxidase; Azo dye; C.I. Reactive Black 5

\section{Introduction}

Azo dyes are the most commonly used dyes in textile dyeing/finishing and also in food, paper and cosmetic industries. Wastewater from these industries is highly colored and the residual azo reactive dyes in it are generally resistant to microbial degradation. Anaerobic reduction and decolorization often generates aryl amines that can be transformed to highly reactive electrophiles and form covalent adducts with DNA, thereby posing a health risk $[1,2]$. Existing physical and chemical technologies (e.g., membrane technologies, coagulation and flocculation technologies) are expensive and might often produce large amounts of solid wastes [3].

Numerous studies have been reported on decolorization of various dyes using white rot fungi, since Tien and Kirk [4]

\footnotetext{
* Corresponding author. Fax: +49 8931873371.

E-mail address: Yediler@gsf.de (A. Yediler).
}

first discovered the lignin peroxidase $(\mathrm{LiP})$ from these fungi. White rot fungi could mineralize many types of different synthetic dyes through their highly oxidative and non-specific ligninolytic enzyme system mainly including lignin peroxidase, manganese-dependent peroxidase (MnP) and laccase [5-7]. Most of the white rot fungi used in the research of wastewater treatment process were Phanerochaet chrysosporium, Trametes versicolor and Coriolus versicolor, and several types of bioreactors using these strains have been proposed in a laboratory scale [3]. However, the aging of fungal mycelium and the risk of contamination by bacteria under non-sterile conditions have hindered the application of white rot fungi in wastewater treatment [3]. On the other hand, yeast, another kind of fungi, has been successfully applied to treat industrial effluents from food, molasses, and oil manufacturing wastewater as reported by Japanese scientists [8,9]. Although several yeasts could also remove dyes through the mechanism of biosorption [10,11], there have 
been few reports on decolorization by yeast through the above ligninolytic enzyme system [12].

In a recent study, we reported about the ability of two yeast isolates, Debaryomyces polymorphus and Candida tropicalis, to produce $\mathrm{MnP}$ and effectively decolorize six different reactive dyes through biodegradation [13]. In this study, the decolorization conditions and $\mathrm{MnP}$ production by $D$. polymorphus were investigated in detail using a widely used azo dye, C.I. Reactive Black 5 (RB5).

\section{Materials and methods}

\subsection{Dye}

C.I. Reactive Black 5 (Color Index) was obtained from Dystar (Germany) as dye formulation Remazol Schwarz B with $75 \%$ purity. The stock solution $\left(10 \mathrm{~g} \mathrm{l}^{-1}\right)$ was neutralized by $0.1 \mathrm{M} \mathrm{HCl}$ and diluted before use. Hydrolization of the dye was accomplished by dissolving the dye in distilled water, adjusting the $\mathrm{pH}$ to 10 with $1 \mathrm{~N} \mathrm{NaOH}$ and boiling at $95^{\circ} \mathrm{C}$ for $3 \mathrm{~h}$ under reflux conditions to simulate the dyehouse processes. The solutions were sterilized by membrane filtration (pore size, $0.45 \mu \mathrm{m}$ ).

\subsection{Microorganism}

D. polymorphus (Y1-0813) was isolated from a municipal wastewater treatment plant in Munich, Germany and preserved in the China General Microbiological Culture Collection Center (CGMCC). The yeast was cultivated at $28^{\circ} \mathrm{C}$, $140 \mathrm{rpm}$ in the following medium: glucose $5 \mathrm{~g}, \mathrm{KH}_{2} \mathrm{PO}_{4} 1 \mathrm{~g}$, $\left(\mathrm{NH}_{4}\right)_{2} \mathrm{SO}_{4} 1 \mathrm{~g}, \mathrm{MgSO}_{4} \cdot 7 \mathrm{H}_{2} \mathrm{O} 500 \mathrm{mg}$, yeast extract $200 \mathrm{mg}$, tap water $1000 \mathrm{ml}$, pH 5.0-6.0.

\subsection{Determination of optimum conditions for decolorization of $R B 5$}

RB5 of $200 \mathrm{mg}^{-1}$ was used throughout the decolorization experiments. Color removal efficiency was determined using the same method as reported previously [18]. To find a suitable amount of inoculum for the effective dye biodegradation by $D$. polymorphus, experiments were performed in $50 \mathrm{ml}$ medium inoculated with three different inoculum sizes (1.4; 4.0 and $17.0 \mathrm{~g}^{-1}$ wet yeast cells). To detect the effect of initial $\mathrm{pH}$ on decolorization of RB5, the medium was adjusted to $\mathrm{pH} 3-10$ before $1.4 \mathrm{~g} \mathrm{l}^{-1}$ wet yeast cells were inoculated. The optimal carbon sources were determined among glucose, maltose, sucrose and starch at the concentration of $5 \mathrm{~g}^{-1}$, respectively. The effects of initial concentrations of carbon and nitrogen sources on decolorization were examined in a series of dye-bearing medium with different concentrations of glucose $\left(0-5 \mathrm{~g}^{-1}\right)$ and ammonium sulphate $\left(0-0.5 \mathrm{~g}^{-1}\right)$, respectively.

\subsection{Effect of initial dye concentration on decolorization}

Effects of initial dye concentrations on RB5 decolorization were evaluated in $50 \mathrm{ml}$ medium containing $5 \mathrm{~g} \mathrm{l}^{-1}$ glucose, $0.5 \mathrm{~g} \mathrm{l}^{-1}$ ammonium sulphate ( $\mathrm{pH}$ ) by inoculating $1.4 \mathrm{~g} \mathrm{l}^{-1}$ wet yeast cells. Four different initial dye concentrations of 100, 200, 300, 400 and $1000 \mathrm{mg}^{-1}$ RB5 were used.

\subsection{Assay of manganese-dependent peroxidase}

MnP activity was detected using 3-di methyl amino benzoic acid/3-methyl-2-benzo-thiazlinoe-hydrazone (DMAB/ $\mathrm{MBTH})$ as described by Lang et al. [14]. One unit (U) of the enzyme activity was defined as the amount of enzyme required to produce $1 \mu \mathrm{mol}$ of product per minute.

\section{Results}

\subsection{Determination of optimum conditions for decolorization}

Complete color removal was obtained within $24 \mathrm{~h}$ cultivation under the three inoculum sizes. The amount of the inoculum of the yeast was thus set at $1.4 \mathrm{~g} \mathrm{l}^{-1}$ wet weight in the following experiments.

The effect of initial $\mathrm{pH}$ values on color removal of C.I. Reactive Black 5 by D. polymorphus and the corresponding final $\mathrm{pH}$ values after $48 \mathrm{~h}$ cultivation are given in Table 1. Maximum color removal was obtained in a $\mathrm{pH}$ range of 5-7. A significant $\mathrm{pH}$ decrease was observed at all the $\mathrm{pH}$ conditions after $48 \mathrm{~h}$ cultivation. Maximum $\mathrm{pH}$ reduction was observed at the optimum decolorization and a $\mathrm{pH}$ range of 5-7. The decolorization of RB5 was accompanied by the production of acids suggesting that $\mathrm{SO}_{3}$ groups were released from the structure of RB5 during the decolorization process.

The effect of carbon source types on decolorization was also investigated (Fig. 1). Except for starch, D. polymorphus could grow in other three carbon sources and effectively decolorize the dye in the medium.

Table 1

Effect of initial $\mathrm{pH}$ value on decolorization efficiency of C.I. Reactive Black 5 by D. polymorphus and the final $\mathrm{pH}$ value of the cultures after $48 \mathrm{~h}$ cultivation

\begin{tabular}{|c|c|c|c|c|c|c|c|c|}
\hline & \multicolumn{8}{|c|}{ Initial $\mathrm{pH}$} \\
\hline & 3.0 & 4.0 & 5.0 & 6.0 & 7.0 & 8.0 & 9.0 & 10.0 \\
\hline Color removal (\%) & 86.4 & 87.4 & 97.9 & 98.6 & 98.9 & 76.7 & 65.6 & 27.7 \\
\hline Final $\mathrm{pH}$ & 1.52 & 1.52 & 1.55 & 1.78 & 2.16 & 5.03 & 5.89 & 9.25 \\
\hline
\end{tabular}




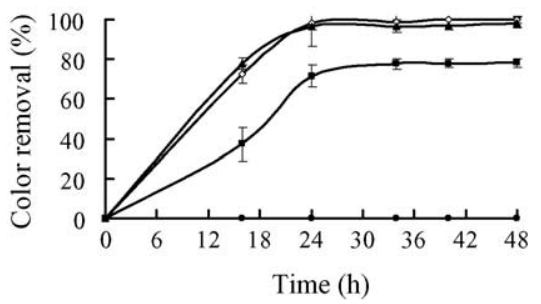

Fig. 1. Effect of various kinds of carbon sources on decolorization of C.I. Reactive Black 5 by D. polymorphus at the initial concentrations of $200 \mathrm{mg}^{-1}$ for dye and $5 \mathrm{~g}^{-1}$ for carbon sources: $(\boldsymbol{\Lambda})$ sucrose; $(\diamond)$ glucose; (ם) maltose; (-) starch.

The decolorization efficiencies by $D$. polymorphus at different glucose and ammonium sulphate concentrations are shown in Table 2. The highest decolorization efficiency (95-98\%) was obtained under the condition of $5 \mathrm{~g}^{-1}$ glucose and $0.5-1.0 \mathrm{gl}^{-1}\left(\mathrm{NH}_{4}\right)_{2} \mathrm{SO}_{4}$. It was clear that the decolorization depended strongly on the presence of glucose in the medium.

Dyes in effluents from the textile dyeing and finishing industry are often in hydrolyzed forms [15]. Therefore, a decolorization test of $200 \mathrm{mg} \mathrm{l}^{-1}$ hydrolyzed RB5 by $D$. polymorphus was performed. $98 \%$ color removal was obtained within $24 \mathrm{~h}$. No significant difference was observed between the decolorization of hydrolyzed and non-hydrolyzed RB5 by $D$. polymorphus.

\subsection{Effect of initial dye concentration on the decolorization process}

The color removals of C.I. Reactive Black 5 over $66 \mathrm{~h}$ were monitored, and extensive decolorization by $D$. polymorphus was observed at all the initial dye concentrations (Fig. 2). The decolorization process could be divided into two stages: a rapid degradation stage within the first $16 \mathrm{~h}$ and a slow decolorization stage thereafter. The dye was removed mainly by biodegradation during the first stage because the cells remained colorless even under high dye concentrations. Biosorption of this azo reactive dye might have occurred along with progress of cultivation time, especially at high initial dye concentrations. The second stage contributed $2.7-25 \%$ of the color removal.

Table 2

Decolorization (\%) of C.I. Reactive Black 5 by D. polymorphus at various carbon and nitrogen concentrations $(48 \mathrm{~h})$

\begin{tabular}{lllll}
\hline$\left(\mathrm{NH}_{4}\right)_{2} \mathrm{SO}_{4}\left(\mathrm{~g} \mathrm{l}^{-1}\right)$ & \multicolumn{4}{l}{ Glucose $\left(\mathrm{g} \mathrm{l}^{-1}\right)$} \\
\cline { 2 - 5 } & 5.0 & 2.5 & 1.0 & 0 \\
\hline 1.0 & 98.6 & 70.0 & 63.5 & 1.5 \\
0.5 & 98.4 & 68.2 & - & - \\
0.1 & 62.4 & - & 59.4 & - \\
0 & 57.4 & - & - & 4.1
\end{tabular}

(-) Not determined.

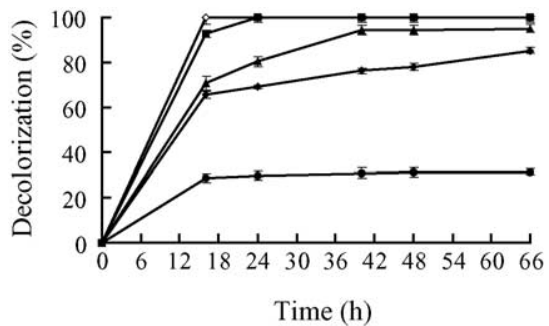

Fig. 2. Decolorization of C.I. Reactive Black 5 by D. polymorphus at various initial dye concentrations: $(\diamond) 100 \mathrm{mg} \mathrm{l}^{-1}$; (ロ) $200 \mathrm{mg} \mathrm{l}^{-1}$; (ム) $300 \mathrm{mg} \mathrm{l}^{-1}$; $(\diamond) 400 \mathrm{mg} \mathrm{l}^{-1} ;(\bullet) 1000 \mathrm{mg}^{-1}$.

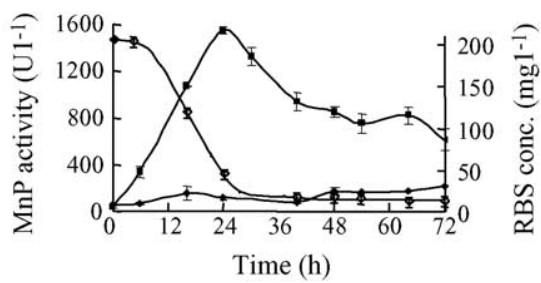

Fig. 3. $\mathrm{MnP}$ activities and residual concentrations of C.I. Reactive Black 5 in $D$. polymorphus cultures: $(\checkmark) \mathrm{MnP}$ activities in the culture without dye added; (ם) MnP activities in the culture with $200 \mathrm{mg}^{-1} \mathrm{RB} 5$ added; $(\diamond)$ residual concentrations of RB5.

\subsection{Kinetics of MnP production}

$\mathrm{MnP}$ activities in D. polymorphus cultures with $200 \mathrm{mg}^{-1}$ RB5 and without the azo reactive dye are given in Fig. 3. MnP activity could be detected after $6 \mathrm{~h}$ cultivation and reached the maximum value of $1555 \mathrm{U} \mathrm{l}^{-1}$ at $24 \mathrm{~h}$ under the presence of RB5. Afterwards, the MnP activity decreased gradually. The MnP activity in the culture without dye was very low over the whole cultivation period compared to the dye-bearing culture. The presence of C.I. Reactive Black 5 was indispensable to the $\mathrm{MnP}$ production.

The residual concentrations of RB5 during cultivation time were detected and compared with corresponding $\mathrm{MnP}$ activity as given in Fig. 3. The rapid drop of residual RB5 concentration within $24 \mathrm{~h}$ matched well with the increase of $\mathrm{MnP}$ activity. The enzyme of MnP could not be further produced by $D$. polymorphus when the residual dye was reduced to a very low level.

\section{Discussion}

D. polymorphus needed barely $24 \mathrm{~h}$ to decolorize the culture medium containing $200 \mathrm{mg} \mathrm{l}^{-1} \mathrm{RB} 5$, which was much shorter than 7-20 days over $90 \%$ color removal using white rot fungi (Phanerochaete chysosporium and Pleurotus sajorcaju) as reported by Chagas and Durrant [5]. Young and $\mathrm{Yu}$ [16] compared the decolorization efficiencies of eight different synthetic dyes including RB5 by LiP, $P$. chrysosporium and $T$. versicolor, respectively. Their results indicated that 
final decolorization of $50 \mathrm{mg}^{-1} \mathrm{RB} 5$ after 9 days of cultivation was $91.4,11.3$ and $15.6 \%$, respectively. The decolorization efficiency by $D$. polymorphus in the present study was significantly high. Another yeast, Kluyveromyces marxianus IBM3 reported by Meehan et al. (2000) could also almost completely decolorize $200 \mathrm{mg} \mathrm{l}^{-1}$ Remazol Black-B $(98 \%$ decolorization) within $24 \mathrm{~h}$ but mainly through physical adsorption of the dye to cellular biomass, not by enzymatic degradation [11].

According to Wang and Yu's report on Tramentes versicolor, a rapid process of dye adsorption was first observed on the cells and then gradual biodegradation occurred through enzymatic reactions [17]. The same mechanism was not observed in this study of dye decolorization by $D$. polymorphus. It was possible that biodegradation of RB5 by $D$. polymorphus was too fast to observe biosorption phenomenon during the first decolorization stage.

In this study, D. polymorphus could not use the dye as a sole carbon source for the cell growth and for enzyme production under the experimental conditions. The dependence of decolorization by $D$. polymorphus on an additional carbon source implies a cometabolic pathway of degradation of aromatic compounds, which was also reported for decolorization of synthesized azo dyes by white rot fungi $[18,19]$. Dye decolorization by $P$. chrysosporium occurred only after $\mathrm{N}$ depletion and was poor in N-rich cultures [20]. However, the decolorization efficiency of $D$. polymorphus depended on a sufficient nitrogen source, which was quite different from most of the cases in white rot fungi [17,21,22].

Our results showed that the presence of RB5 was a necessary condition for $\mathrm{MnP}$ production. In our previous experiments, at least four other dyes, C.I. Reactive Red M-3BE, Procion Scharlach H-E3G, Procion Marine H-EXL (BASF) and C.I. Reactive Brilliant Red $K-2 B P$, could also induce the enzyme production [13]. It was obvious that $\mathrm{MnP}$ was an important enzyme responsible for degradation of different kinds of dyes. However, it seemed that the presence of only MnP was not enough for color removal of RB5. From Fig. 3, we can see that a small amount of residual color could not be removed after $24 \mathrm{~h}$ cultivation even though the MnP activity was still high. Results of our further experiments indicated that the decolorization process ceased immediately after the glucose was depleted even $\mathrm{MnP}$ activity remained high in the culture. A condition of slow depletion of glucose, such as using yeast cells preserved in the refrigerator in advance for several days as inoculum, or increasing the concentration of glucose will be helpful for complete color removal. Further research is needed to clarify the mechanism of dye decolorization by $D$. polymorphus.

\section{Acknowledgements}

This work was conducted at the GSF Institute of Ecological Chemistry funded by the German Federal Min- istry of Education, Science, Research and Technology (BMBF), and by the National Natural Science Foundation of China (Grants 50278095) and the Natural Science Foundation of Henan Province, China (Grants number: 0411032400).

\section{References}

[1] W.G. Tarpley, J.A. Miller, E.C. Miller, Adducts from the reaction of $N$-benzyloxy- $N$-methyl-4-aminoazobenzene with deoxyguanosine or DNA in vitro and from hepatic DNA of mice treated with $\mathrm{N}$ methyl-or $N, N$-dimethyl-4-aminoazobenzene, Cancer Res. 40 (1980) 2493-2499.

[2] E.S. Yoo, J. Libra, L. Adrian, Mechanism of decolorization of azo dyes in anaerobic mixed culture, J. Environ. Eng. 127 (2001) 844-849.

[3] M. Borchert, A.L. Judy, Decolorization of reactive dyes by the white rot fungus Trametes versicolor in sequencing batch reactors, Biotechnol. Bioeng. 75 (2001) 313-321.

[4] M. Tien, T.K. Kirk, Lignin peroxidases of Phanerochaete chrysosporium, Methods Enzymol. 161 (1988) 238-249.

[5] E.P. Chagas, L.R. Durrant, Decolorization of azo dyes by phanerochaete chrysoporium and Pleurotus sajorcaju, Enzyme Microb. Technol. 29 (2001) 473-477.

[6] M. Chivukula, V. Renganathan, Phenolic azo dyes oxidation by laccase from Pyricularia oryzae, Appl. Environ. Microbiol. 61 (1995) 4374-4377.

[7] A. Heinfling, M. Bergbauer, U. Szewzyk, Biodegradation of azo and phthalocyanine dyes by Trameters versicolor and Bjerkandera adusta, Appl. Microbiol. Biotechnol. 48 (1997) 261-266.

[8] K. Moriya, H. Iefuji, H. Shimoi, S. Sato, M. Tadenuma, Treatment of distillery wastewater discharged from beet molassesspirits production using yeast, J. Ferment. Bioeng. 69 (1990) 138140.

[9] K. Chigusa, T. Hasegawa, N. Yamamoto, Y. Watanabe, Treatment of wastewater from oil manufacturing plant by yeasts, Water Sci. Technol. 34 (1996) 51-58.

[10] M.A.M. Martins, M.H. Cardoso, M.J. Queiroz, Biodegradation of azo dyes by the yeast Candida zeylanoides in batch aerated cultures, Chemosphere 38 (1999) 2455-2460.

[11] C. Meehan, I.M. Banat, G. McMullan, Decolorization of remazol black-B using a thermotolerant yeast, Kluyveromyces marxianus IMB3, Environ. Int. 26 (2000) 75-79.

[12] M. Hofrichter, Review: lignin conversion by manganese peroxidase (MnP), Enzyme Microb. Technol. 30 (2002) 454-466.

[13] Q. Yang, M. Yang, K. Pritsch, A. Yediler, A. Hagn, M. Schloter, A. Kettrup, Decolorization of synthetic dyes and production of manganese-dependent peroxidase by new fungal isolates, Biotechnol. Lett. 25 (2003) 709-713.

[14] E. Lang, G. Eller, F. Zadrazil, Lignocellulose decomposition and production of ligninolytic enzymes during interaction of white rot fungi with soil microorganism, Microb. Ecol. 34 (1997) $1-10$.

[15] A. Yediler, D. Lienert, M. Koch, A. Kettrup, F. Germirli-Babuna, D. Karatas, G. Insel, D. Orhon, Appropriate technologies for the minimization of environmental impact from industrial wastewaterstextile industry: a case study (AZ: 11/72146). Final report submitted to Volkswagen-Foundation, Germany, 2001.

[16] L. Young, J. Yu, Ligninase-catalysed decolorization of synthetic dyes, Water Res. 31 (1997) 1187-1193.

[17] Y. Wang, J. Yu, Adsorption and degradation of synthetic dyes on the mycelium of Trametes versicolor, Water Sci. Technol. 38 (1998) 233-238. 
[18] M. Adosinda, M. Martins, I.C. Ferreira, I.M. Santos, M.J. Queiroz, N. Lima, Biodegradation of bioaccessible textile azo dyes by Phanerochaete crysosporium, J. Biotechnol. 89 (2001) 91-98.

[19] J. Swamy, J.A. Ramsay, Effects of glucose and $\mathrm{NH}_{4}{ }^{+}$concentrations on sequential dye decoloration by Trametes versicolor, Enzyme Microb. Technol. 25 (1999) 278-284.
[20] T.K. Kirk, E. Schultz, W.J. Connors, L.F. Lorenz, J.G. Zeikus, Influence of culture parameters on lignin metabolism by Phanerochaete crysosporium, Arch. Microbiol. 117 (1978) 277-285.

[21] Y. Wong, J. Yu, Laccase catalysed decolorization of synthetic dyes, Water Res. 33 (1999) 3512-3520.

[22] Y. Fu, Viraraghavan, Fungal decolorization of dye wastewaters: a review, Bioresour. Technol. 79 (2001) 251-262. 